\section{Getting Into the Weeds}

Even though I went to college in the 1960s in San Francisco, I actually have very little experience with cannabis. Honest! But now I think I need to know more; not for me, but for the sake of my patients. We've had medicinal marijuana for a long time, but now California has legalized recreational use and it's getting complicated.

I was at a regional meeting recently and we were discussing causes and management of delirium in patients with cancer. I commented that I was seeing a lot more delirium related to cannabis than ever before. Pretty soon, heads were wagging around the room. Our patients are misusing cannabis, and as a result, they are falling and getting injured, being sent to the emergency room and undergoing unnecessary imaging and blood tests, mixing up their regular medications, and the list goes on.

Why is this happening now? I think it is probably because marijuana is readily available, and well-meaning friends and family are bringing patients all sorts of cannabis products, such as edibles and oils, in varying potencies and quantities. Of course, the simple fix here is to recommend that our patients only use marijuana from a medicinal dispensary where, hopefully, they will get good advice. But shouldn't we do more?

I'm fortunate to work with a talented faculty with diverse interests, and I was particularly interested in a presentation last week by Donald Abrams, MD, an expert in complementary and alternative medicine. He gave an excellent seminar on cannabis and explained that there are more than 400 chemical compounds in cannabis. Depending on the plant used, the amount of tetrahydrocannabinol (THC) - the psychoactive componentand the other 100 cannabinoids can vary from $1 \%$ to $20 \%$, usually inversely to each other. The other cannabinoids and noncannabinoids can enhance some of the effects of THC and may have some immune-enhancing or -suppressing effects. Who knew?

My point here is that I suspect that few of us know much about the medicinal properties of cannabis, yet most of our patients are using it. The literature that is available is scant and disorganized. Well-done clinical studies are nearly nonexistent. I think we need more studies (are you listening, NIH?) and we need to establish a curriculum for providers that can help us navigate this with our patients. Right now, I still feel pretty ignorant.

I do believe that cannabis can help our patients-it can improve sleep, control nausea, and reduce anxiety, among other benefits. But cannabis used improperly undoubtedly adds medical complications that can harm our patients and add to the cost of care. So, I think this is a real issue that we need to address.

If we can master knowledge about the complex mechanisms of action of anticancer drugs, we can take on cannabis. We need experts like Donald to organize the information for us, and we need to be willing to create some educational and clinical partnerships with the dispensaries that serve our patients. After all, we have the same goal: help them feel better!

What do you think? Please e-mail correspondence (include contact information) to JNCCN@nccn.org or log into www.editiorialmanager.com/JNCCN to submit a Letter to the Editor.

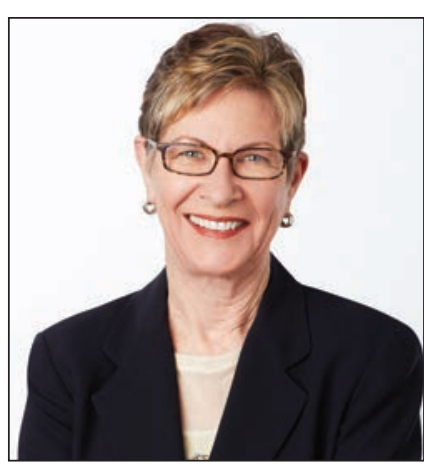

Margaret Tempero, MD

Margaret Tempero, MD, is a Professor of Medicine and Director of the UCSF Pancreas Center and editor-in-chief of JNCCN. Her research career has focused on pancreatic ductal adenocarcinoma, especially in the area of investigational therapeutics. Dr. Tempero has served on the ASCO Board of Directors and as ASCO President. She currently serves on the ASCO Conquer Cancer Foundation Board. She codirected the AACR/ASCO Methods in Clinical Cancer Research and taught this course and similar courses in Europe and Australia. She was founding Chair of the $\mathrm{NCl}$ Clinical Oncology Study Section and served as a member and Chair of the $\mathrm{NCl}$ Board of Scientific Counselors Subcommittee A. She is a member of the Scientific Steering Committee and Chair of the Clinical and Translational Study Section for the Cancer Prevention \& Research Institute of Texas. She is or has been on the Scientific Advisory Boards of the Lustgarten Foundation, the Pancreatic Cancer Action Network, the $V$ Foundation, The Alberta Canada Cancer Board, and the EORTC. She served as a member of the Oncology Drug Advisory Committee for the FDA. She has served as Deputy Director and Interim Director for the UNMC Eppley Cancer Center. She is Chief Emeritus of the Division of Medical Oncology at UCSF and served as the founding Deputy Director and Director of Research Programs at the UCSF Helen Diller Family Comprehensive Cancer Center.

doi: 10.6004/jncen.2018.0027

The ideas and viewpoints expressed in this editorial are those of the author and do not necessarily represent any policy, position, or program of NCCN. 